Mesozoic (150 m.y.) event. The Mistral basement is probably related to the lower Paleozoic Caledonides of South France (Géze, 1960). Graptolite-bearing phyllites and sandstone are present in the Maures Massif on the coast between Toulon and Cannes and in the Montagne-Noire east of, and northwest of, the Gulf of Lyon respectively (Gignoux, 1960 , p. 109-110). Like the rocks on Sardinia, the Cambrian-Ordovician series of the Montagne Noire seems to record a Hercynian tectonic and thermal event as well (Géze et al., 1962; Mattauer et al., 1967).

\section{DISCUSSION}

Samples from these three widely separate regions are sedimentologically very similar: all belong to the graywacke-suite and are derived from a similar source terrain. Their deformational and metamorphic histories also show remarkably parallel trends. All were mildly metamorphosed. The Sardinia samples seem to have undergone the most advanced metamorphism and have lost much of their original clastic textures. Sardinia Slope and Mistral samples are fine-grained and less recrystallized. Although the samples from all these regions include sericite and chlorite as metamorphic minerals, the existence of potash feldspar and plagioclases, more calcic than albite, indicate that the rocks have not yet been equilibrated under conditions of greenschist metamorphism; the detrital feldspar grains represent unstable relics. The development of slaty cleavage inclined to the bedding surfaces has been observed in all three suites of samples. This feature would place all suites in the slate belt of a mountain system.
The similarity of the offshore "basement" to the proximal Caledonides on land suggests to us that both the Sardinia Slope and the Gulf of Lyon basement belong also to the Caledonides. Southern France and Sardinia are now separated by the Balearic Basin. Nevertheless, an affinity between the French and Sardinia Caledonides was already noted by Gignoux (1960). Our Sardinia Slope and Gulf of Lyon samples now provide us with an even closer link. The metagraywackes and phyllites from our holes could well represent the western and offshore prolongation of the Caledonides of the Maures Massif if we accept Argand's geometrical restoration of the Carso-Sardinia block.

\section{REFERENCES}

Argand, E., 1922. Le Tectonicque de l'Asie, Congrés géol. intern., XIII, Belgium, Comp. rendus. 171.

Gèze, B., 1960. L'Orogenèse caladonienne dans la Montagne Noire (sud du Massif Central français) et les régions voisines. Intern. Geol. Congr., 21st, Copenhagen, 1960, Rept. Session, Norden, 19, 120.

Gèze, B., DeSitter, L. V. and Trumpy, R., 1952. Sur le sens de deversement des nappes de la Montagne Noire. Bull. Soc. Géol. France. 6 (2), 491.

Gignoux, M., 1960. Geologie Stratigraphique. Masson et Cie., Paris. 759.

Jung, J., 1953. Zonéographie et âge des formations crystallophylliennes et des massifs hercyniens française. Bull. Soc. G'eol. France. 235, 1.

Mattauer, M., Arthaud, F. and Proust, F., 1967. La structure et la microtectonique des rappes herciennes de la Montagne Noire. In J. P. Schaer (Editor), Colloque Etages Tectoniques, Baconniere, Neuchatel. 229.

\title{
29.2. ISOTOPIC DATING, SARDINIA SLOPE BASEMENT
}

\author{
U. Frick, R. H. Steiger and K. J. Hsü, Geologisches Institute Eidg. Technische Hochschule, Zurich, Switzerland
}

Two samples from the Sardinia Slope basement, 13-134-D-3-CC and 13-134-B-1-CC, were sent to the Laboratory of Isotope Geochemistry and Mass Spectrometry, Swiss Federal Institute of Technology, Zurich, for isotopic dating. The first is a fine-grained metagraywacke, the second a phyllite. The rocks consist mainly of quartz, sericite, and chlorite; the very fine-grained sericite is the main potassium-bearing mineral. However, the graywacke specimen (13-134-D-3-CC) includes a few per cent of potash feldspar, which may represent unstable relics of detrital origin. The detailed petrographic descriptions of these samples are included in Chapter 29.1.

Because it was not possible to separate grains of sericite, which are only several microns in size, it was necessary to do whole-rock K/A dating. The analytical data are shown in Table 1.

The computed ages are derived from the ratio of potassium and radiogenic argon. The geological significance
TABLE 1

Radiometric Dating of Sardinia Slope Basement

\begin{tabular}{l|c|c}
\cline { 2 - 3 } & \multicolumn{2}{c}{ Sample No. } \\
\cline { 2 - 3 } & 13-134-D-3-CC & $13-134-\mathrm{B}-1-\mathrm{CC}$ \\
\hline Lithology & Metagraywacke & Phyllite \\
Potassium content & & \\
$\quad$ by isotopic dilution & $2.32 \%$ & $3.75 \%$ \\
$\quad$ by atomic-absorption & $2.10 \%$ & $3.69 \%$ \\
rad. Ar 40 cc STP & $1.89 \pm 0.05 \times 10^{-5}$ & $1.82 \pm 0.05 \times 10^{-5}$ \\
Air argon & $19.1 \%$ & $18.4 \%$ \\
Computed age & $210 \pm 15$ & $120 \pm 5$ \\
\hline
\end{tabular}

of the ages is very questionable since whole-rock dating of metamorphic rocks is a rather unsatisfactory method. There is the problem of inherited argon from detrital minerals in such mildly metamorphosed graywackes and phyllites. 
Further, the question of argon loss during an extended cooling process must be considered.

Geologically, the basement of the Sardinia Slope has been correlated with the Caledonides on land, which has been affected by the Hercynian metamorphism (Cocozza, personal communcation). Results from the metagraywacke analysis, seem to support this conclusion. Yet the phyllite sample, collected less than a kilometer away, and from the same geological formation, gives a much lower apparent age. This discrepancy may be related to the relic grains of detrital $\mathrm{K}$-feldspar, which is present in the graywacke but absent in the phyllite. We may speculate, on the basis of geological reasoning, that the graywacke date might more nearly represent the age of metamorphism, but this conclusion is not directly supported by any of the isotopic data we have. 